\title{
PENGARUH INTELLECTUAL CAPITAL (IC) TERHADAP FINANCIAL PERFORMANCE PADA PERUSAHAAN SEKTOR PERBANKAN YANG TERDAFTAR DI BURSA EFEK INDONESIA
}

\author{
The Influence of Intellectual Capital (IC) to Financial Performance \\ in Banking Sector Listed in the Indonesia Stock Exchange
}

\author{
Abdul Salam ${ }^{1}$ \\ ${ }^{1}$ Program Studi Manajemen, Fakultas Ekonomi dan Bisnis, Universitas Teknologi Sumbawa \\ *)Email : abdul.salam2008@gmail.com
}

\begin{abstract}
This study aimed to examine the influence of Intellectual capital (IC) to financial performance of the company in banki sector during the period of 2010 to 2014 in Indonesia Stock Exhange in forms used of panel data. Intellectual Capital is proxied from the method value added intellectual coefficient (VAIC $\mathrm{TM}$ ) its components value added human capital (VAHU), value added capital employe (VACA), and structural capital value added (STVA) is applied for measure the value based performance. Meanwhile, financial performance is proxied by return on assets (ROA). Tools Analysis used in this research is multivariable linear regression by applying Fixed Effect Model (FEM) Method with sample obtained from 24 banks. Sampling technique in this research is based on purposive sampling. Based on The Chow test, Hausman test and Lagrange Multiplier (LM) test resulted to use fixed effect model in that panel data regression procedure. The results show that STVA and VAIC ${ }^{\mathrm{TM}}$ has positive influence and significant on ROA. Meanwhile VAHU and VACA has positive influence and not significant on ROA. The F test resulted to show Adjusted R-square with coefficient at 0.381370. which mean that VAHU, VACA, STVA and ROA has a causal relationship with banking sector amounted to $3.81370 \%$ and the remaining $61.827 \%$ is explained by other variables and factors not examined in this research.
\end{abstract}

Keyword: Intellectual Capital, Financial Performance, Fixed Effect Model, Banking Sector

\begin{abstract}
ABSTRAK
Penelitian ini bertujuan untuk menguji pengaruh intellectual capital terhadap financial perforrmance perusahaan di sektor perbankan di Bursa Efek Indonesia periode 2010 sampai 2014 dengan menggunakan data panel. Intellectual Capital di proksikan dengan metode value added intellectual coefficient (VAIC ${ }^{\mathrm{TM}}$ ) dengan komponennya value added human capital (VAHU), value added capital employe (VACA), dan structural capital value added (STVA) digunakan untuk mengukur nilai dasar kinerja bank, sedangkan Financial Performance di proksikan dengan return on assets (ROA). Alat analisa yang digunakan adalah regresi liner multivariabel dengan penerapan metode model Fixed Effect dengan sampel dari 24 bank dengan purposive sampling, berdasarkan hasil test Chow, Test Hausman, Test Lagrange Multiplier (LM) maka penelitian ini mengunakan prosedur Model Fixed Effect. Hasil penelitian ini menununjukkan bahwa STVA dan VAIC TM berdampak positif dan signifikan terhadap ROA. Sedangkan VACA dan VAHU berpengaruh positif dan tidak signifikan terhadap ROA. Hasil Uji F (Simultan) besarnya nilai Adjusted R-squared yaitu 0.381370 yang berarti bahwa variasi variabel ROA dapat dijelaskan oleh variabel VAHU, VACA dan STVA adalah sebesar 0.381370 atau sebesar $38.1370 \%$ sedangkan sisanya sebesar $61.827 \%$ dijelaskan oleh faktor-faktor lain yang tidak terdapat dalam penelitian ini.
\end{abstract}

Keyword: Intellectual Capital, Financial Performance, Fixed Effect Model, Banking Sector.

\section{Pendahuluan}

Kinerja sektor perbankan di Indonesia dan kaitannya dengan sektor riil relatif cukup fluktuatif. Era globalisasi telah mendorong munculnya new economy menjadikan perekonomian dunia saling terkait satu sama lain (borderless), dimana kompetensi yang tinggi dalam bidang ilmu pengetahuan dan teknologi merupakan faktor daya saing yang sangat dibutuhkan bagi pebisnis dibidang perbankan guna menciptakan inovasi-inovasi demi kesinambungan pertumbuhan perusahaan. Persaingan bisnis yang sangat kompetitif ini mendorong sektor perbankan untuk mengubah strategi bisnis yang awalnya didasarkan pada labor-based bussiness menjadi knowlegde-based bussiness.

Mengukur intellectual capital (IC) dapat membantu mengevaluasi ukuran dan kinerja perusahaan, tidak hanya aset fisik, tetapi juga aset tidak berwujud, 
intellectual capital dianggap sebagai potensi sumber daya strategis korporasi yang efektif dalam penciptaan nilai (Zeghal dan Maaloul, 2010). Beberapa metode telah dikembangkan untuk mengukur intellectual capital yang dapat digunakan untuk mengevaluasi perusahaan. Salah satu metode ini adalah value added intellectual coefficient (VAIC ${ }^{\mathrm{TM}}$ ) (Pulic, 2004). Metode ini mempertimbangkan nilai yang diciptakan oleh aset tidak berwujud maupun aset berwujud yang cukup komprehensif diantara metode lain saat ini (Kujansivu dan Lonngvist, 2007).

Pengelolaan modal intelektual secara efektif sangat diperlukan agar dapat mendorong pertumbuhan kinerja perusahaan. Riahi-Belkaoui (2003) penelitiannya menunjukkan bahwa ada hubungan positif yang signifikan antara modal intelektual dan kinerja perusahaan. Bahkan VAICTM dapat digunakan sebagai indikator untuk memprediksi kinerja perusahaan di masa mendatang. Firer dan Williams (2003) bahwa perusahaan di Afrika Selatan lebih menganggap sumber daya fisik sebagai faktor utama dalam menciptakan nilai dibandingkan dengan sumber daya modal dan IC.

Bontis (1998) terdapat suatu kebenaran, dapat diandalkan, signifikan, dan hubungan sebab akibat yang mendasar antara dimensi intellectual capital dan kinerja perusahaan. Tan et al., (2007) bahwa IC dan financial performance mempunyai hubungan positif; IC berkorelasi dan IC mempunyai hubungan positif terhadap kinerja perusahaan, dan kontribusi IC terhadap kinerja perusahaan di industri yang berbeda. Rudez dan Mihalic (2007) terdapat hubungan positif antara komponen IC dan financial performance. Mereka juga menemukan bahwa akhir customer relationship mempunyai dampak langsung yang kuat terhadap kinerja keuangannya.

Richieri et al., (2008) ada hubungan positif antara perhitungan kedua nilai tak berwujud dan intellectual capital efficiency dan variabel dependen ROE, ROA, dan ROS. Ting dan Lean (2009) bahwa VAIC ${ }^{\text {TM }}$ dan ROA mempunyai hubungan yang positif. Selanjutnya hasil penelitian ini terdapat hubungan yang relevan ketiga komponen VAIC ${ }^{\text {TM }}$ dengan profitabilitas: human capital dan capital employed mempunyai hubungan positif, selain itu structural capital mempunyai hubungan yang negatif terhadap profitabilitas.

Nogueira et al., (2010) intellectual capital yang berdampak positif terhadap profitabilitas, berpengaruh positif signifikan hubungan antara VAICTM dan profitabilitas pada perusahaan di Brazil. Zeghal dan Maaloul (2010) penelitiannya menggunakan analisis multiple regresi menunjukkan pengaruh positif signifikan hubungan antara VAIC ${ }^{\text {TM }}$ dan kinerja perekonomian dan antara VAIC ${ }^{\mathrm{TM}}$ dan financial performance. Hubungan antara VAICTM dan kinerja bursa efek hanya signifikan untuk industri padat teknologi. Abdullah dan Sofian (2012) semua komponen IC mempunyai hubungan positif yang signifikan dengan kinerja perusahaan. Selanjutnya, relational capital sudah dilaporkan sebagai komponen yang berhubungan kuat dengan kinerja perusahaan perusahaan Publik di Malaysia.

Salehi et al., (2014) meneliti hubungan antara intellectual capital (IC) dengan economic value added (EVA) dan financial performance Hasil analisis dengan regresi multivariate menolak yang dihipotesiskan, sedangkan hasil penelitian dengan analisis regresi mendukung semua hubungan yang signifikan antara SCE, EVA, dan financial performance

Berdasarkan uraian diatas, maka permasalahan yang akan diteliti dalam penelitian ini khususnya disektor perbankan yang terdaftar di Bursa Efek Indonesia (20102014) sebagai berikut :

1. Apakah value added human capital (VAHU) berpengaruh terhadap financial performance?

2. Apakah value added capital employe (VACA) berpengaruh terhadap financial performance?

3. Apakah structural capital value added (STVA) berpengaruh terhadap financial performance?

4. Apakah Value added intellectual coefficient (VAIC ${ }^{\text {TM }) ~ a t a u ~(V A H U, ~ V A C A, ~ S T V A) ~}$ berpengaruh secara bersama-sama terhadap financial ?

Tujuan dari penelitian adalah sebagai berikut :

1. Untuk mengetahui pengaruh value added human capital (VAHU) berpengaruh terhadap financial performance perusahaan perbankan yang terdaftar di Bursa Efek Indonesia (BEI)

2. Untuk mengetahui pengaruh value added capital employe (VACA) berpengaruh terhadap financial performance perusahaan perbankan yang terdaftar di Bursa Efek Indonesia (BEI)

3. Untuk mengetahui pengaruh structural capital value added (STVA) berpengaruh terhadap financial performance perusahaan perbankan yang terdaftar di Bursa Efek Indonesia (BEI

4. Untuk mengetahui pengaruh Value added intellectual coefficient (VAIC ${ }^{\mathrm{TM}}$ ) secara bersamasama terhadap financial performance perusahaan perbankan yang terdaftar di Bursa Efek Indonesia (BEI) 


\section{Metode Penelitian}

Penelitian ini menggunakan data kuantitatif dengan analisis statistik desktriptif untuk menganalisis karakteristik data, pengujian hubungan langsung antara intellectual capital (IC) terhadap financial performance perusahaan pada sektor perbankan. Statistik deskriptif merupakan rangkuman data dalam bentuk tabel, grafik, dan angka (Anderson et al. 2011). Dalam penelitian ini data yang diinginkan adalah deskripsi data yang dilihat dari mean, maksimum, minimum, dan standar deviasi. Penelitian ini menggunakan teknik pengumpulan data dengan strategi arsip (archival). Menurut Jogiyanto (2004) strategi arsip yaitu untuk mendapatkan data sekunder, teknik pengumpulan data yang dapat digunakan adalah pengumpulan data dari basis data.

Teknik dalam pemilihan sampel yang digunakan adalah dengan metode judgment sampling. Menurut Jogiyanto (2004) Jugdment sampling adalah purposive sampling (pengambilan sampel bertujuan) dilakukan dengan mengambil sampel dari populasi berdasarkan kriteria yang digunakan dapat berdasarkan pertimbangan (judgement) tertentu. Purposive sample yaitu teknik penentuan sampel dengan pertimbangan tertentu (Sugiono, 2011).

Dari Populasi sebanyak 36 emiten bank, selanjutnya yang menjadi sampel adalah 24 emiten bank, kode emitennya adalah sebagai berikut : AGRO, BACA, BAEK, BBCA, BBKP, BBMD, BBNI, BBNP, BBRI, BBTN, BDMN, BJBR, BMRI, BNBA, BNGA, BNII, BNLI, BSIM, BSWD, BTPN, BVIC, INPC, MAYA, MCOR.

Data yang digunakan adalah data sekunder atau data dokumentasi yang diperoleh dari annual report perusahaan sektor perbankan tahun 2010-2014 di Bursa Efek Jakata (BEI), situs resmi perusahaan, www.idx.co.id, Indonesia capital market directory (ICMD) dan telah dipublikasikan untuk memperoleh perhitungan intellectual capital (VAHU, VACA, STVA, $\mathrm{VAIC}^{\mathrm{TM}}$ dan financial performance (ROA).

Menurut Gujarati (2005) adapun persamaan dasar dari regresi linear dua atau tiga variabel, model regresi populasi (PRF) k-variabel meliputi variabel tak bebas $\mathrm{Y}$ dan k-1 variabel yang menjelaskan $\mathrm{X}_{1}, \mathrm{X}_{2}, \mathrm{X}_{3} \ldots \mathrm{X}_{\mathrm{k}}$ atau bisa ditulis sebagai model persamaan regresi pada penelitian ini adalah sebagai berikut :

$\mathrm{ROA}_{\text {it }}=\alpha+\beta_{1} \mathrm{VAHU}_{\text {it }}+\beta_{2} \mathrm{VACA}_{\text {it }}+\beta_{3} \mathrm{STVA}_{\text {it }}+\varepsilon_{\text {it }}$

Dimana :

$$
\begin{array}{ll}
\mathrm{Y} & \text { : Financial Performance (ROA) } \\
\mathrm{X}_{1} & \text { : VAHU }
\end{array}
$$

$$
\begin{array}{ll}
\mathrm{X}_{2} & \text { : VACA } \\
\mathrm{X}_{3} & \text { : STVA } \\
\mathrm{X} & : \text { VAICTM } \\
\mathrm{i} & : 1,2, \ldots, \mathrm{n} \\
\mathrm{t} & : 1,2, \ldots, \mathrm{t} \\
\mathrm{n} & : \text { Banyaknya Emiten } \\
\mathrm{t} & : \text { Banyaknya Waktu } \\
\mathrm{n} \mathrm{x} & : \text { Banyaknya data panel }
\end{array}
$$

Model Analisis ini untuk mengetahui besarnya koefisien regresi pada masing-masing variabel yang akan diteliti. Koefisien regresi ini menguji pengaruh variabel terikat ROA pada masing-masing emiten perbankan, terhadap masing-masing variabel bebas yang terdiri dari VAHU,

\begin{tabular}{|c|c|c|}
\hline Variabel & Indikator & Skala \\
\hline \multirow{4}{*}{ VAIC ${ }^{\mathrm{TM}}$} & $\begin{array}{l}\text { VAHU = value added, } \\
\text { human capital }\end{array}$ & Rasio \\
\hline & $\begin{array}{l}\mathrm{VACA}=\text { value added, } \\
\text { assets }\end{array}$ & Rasio \\
\hline & $\begin{array}{l}\text { STVA = structural } \\
\text { capital, value added }\end{array}$ & Rasio \\
\hline & $\begin{array}{l}\text { VAIC'M }=\text { VAHU }+ \\
\text { VACA }+ \text { STVA }\end{array}$ & Rasio \\
\hline $\begin{array}{l}\text { Financial } \\
\text { Performanc } \\
\text { e (ROA) }\end{array}$ & $\frac{\text { Net Income (NI) }}{\text { Total Asset (TA) }} \times 100 \%$ & Rasio \\
\hline
\end{tabular}
VACA, STVA serta VAIC. Variabel ROA meningkat atau menurun sebesar $\beta_{l}$ unit untuk variabel VAHU meningkat atau menurun sebesar satu unit. Hal yang sama akan terjadi jika variabel bebas lainnya meningkat atau menurun satu unit, maka variabel terikat akan meningkat atau menurun sebesar koefisien regresi variabel tersebut

Tabel 1. Variabel Penelitian, Indikator, Skala dan Sumber

Sumber : Data diolah Peneliti, 2016

\section{Analisis Regresi Data Panel}

Analisis Regresi Data Panel dilakukan untuk menentukan model yang tepat, maka ada beberapa tahap yang harus dilakukan adalah sebagai berikut :

Regresi data panel merupakan teknik regresi yang menggabungkan data time series dengan cross section. Cross section merupakan data yang dikumpulkan dalam satu waktu tertentu terhadap banyak individu. Sedangkan data time series adalah data yang dikumpulkan dari waktu ke waktu terhadap suatu individu. Menurut Widarjono (2010) metode regresi data panel mempunyai beberapa keuntungan jika dibandingkan dengan data time series atau cross section, yaitu:

1) Data panel yang merupakan gabungan dua data time series dan cross section mampu menyediakan 
data yang lebih banyak sehingga akan menghasilkan degree of freedom yang lebih besar. Menggabungkan informasi dari data time series dan cross section dapat mengatasi masalah yang timbul ketika ada masalah pengilangan variabel (omitted-variabel).

Shochrul, et al. (2011) menambahkan keunggulan regresi data panel antara lain:

1) Data panel mampu memperhitungkan heterogenitas individu secara eksplisit dengan mengizinkan variabel spesifik individu.

2) Kemampuan mengontrol heterogenitas ini selanjutnya menjadikan data panel dapat digunakan untuk menguji dan membangun model perilaku lebih kompleks.

3) Data panel mendasar diri pada observasi cross section yang berulang-ulang (time series), sehingga metode data panel cocok digunakan sebagai study of dynamic adjustment.

4) Tingginya jumlah observasi memiliki implikasi pada data yang lebih informatif, lebih variatif, dan kolinieritas (multikolinieritas) antara data semakin berkurang, dan derajat kebebasan (degree of freedom) lebih tinggi sehingga dapat diperoleh hasil estimasi yang lebih efisien.

5) Data panel dapat digunakan untuk mempelajari model-model perilaku yang kompleks.

6) Data panel dapat digunakan untuk meminimalkan bias yang mungkin ditimbulkan oleh agregasi data individu.

Dengan keunggulan tersebut maka implikasinya tidak harus dilakukannya pengujian asumsi klasik dalam metode data panel.

Menurut Nachrowi (2010) dalam analisis model data panel dikenal dengan tiga macam pendekatan estimasi yaitu pendekatan kuadrat terkecil (pooled least square/ordinary least square/common effect), pendekatan efek tetap (fixed effect), dan pendekatan efek acak (random effect). Ketiga pendekatan yang dilakukan dalam analisa data panel ini akan dijelaskan lebih rinci, sebagai berikut :

1. Pooled Least Square/Ordinary Least Square/Common Effect

Teknik ini tidak ubahnya dengan membuat regresi dengan data cross section atau time series. Akan tetapi untuk data panel sebelum membuat regresi harus menggabungkan data cross section dengan data time series (pool data) kemudian data gabungan ini digunakan sebagai satu kesatuan pengamatan yang digunakan untuk mengestimasi model dengan metode OLS. Dalam pendekatan ini tidak memperhatikan dimensi individu maupun waktu, dan dapat diasumsikan bahwa perilaku data antar perusahaan sama dalam berbagai rentang waktu. Asumsi ini jelas sangat jauh dari realita sebenarnya karena karakteristik antar perusahaan jelas sangat berbeda.

2. Fixed Effect

Model fixed effect menggunakan variabel dummy untuk menangkap adanya perbedaan intercep. Metode ini mengasumsikan bahwa koefisien regresi (slope) tetap antar perusahaan dan antar waktu, tetapi intercept-nya berbeda antar perusahaan dan sama antar waktu (time invariant). Namun metode ini membawa kelemahan yaitu berkurangnya derajat kebebasan (degree of freedom) yang pada akhirnya mengurangi efisiensi parameter.

\section{Random Effect}

Pendekatan random effect menambahkan variabel gangguan (error terms) yang mungkin saja akan muncul pada hubungan waktu dan antar individu. Teknik metode OLS tidak dapat digunakan untuk mendapatkan estimator yang efisien, sehingga lebih tepat untuk menggunakan metode Generalized Least Square (GLS).

Untuk memilih pendekatan yang terbaik antara ketiga pendekatan yang telah disebutkan sebelumnya, maka diperlukan pengujian seperti yang dijelaskan pada gambar dibawah ini.

Gambar 1. Proses Pemilihan Model Data Panel

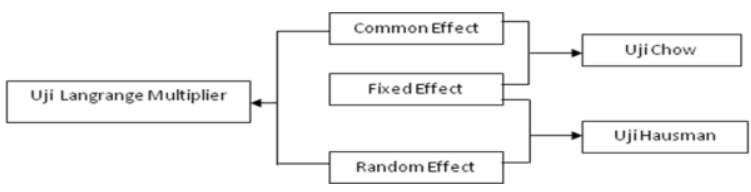

Berikut ini penjelasan mengenai kedua pengujian yang dilakukan dalam proses pemilihan model data panel:

\section{Uji Chow}

Merupakan pengujian yang dilakukan untuk mengetahui apakah model yang digunakan adalah common atau fixed effect. Pengujian dilakukan menggunakan chow test dengan hipotesis sebagai berikut:

$\mathrm{H}_{0}$ : Model menggunakan Common Effect.

$\mathrm{H}_{1}$ : Model menggunakan Fixed Effect.

Uji Chow mengikuti distribusi F statistik, dimana kriteria pengambilan keputusan ialah: 
- Jika $P$-value $>0.05$ maka $\mathrm{H}_{0}$ diterima, model yang digunakan adalah Common Effect.

- Jika $P$-value < 0.05 maka $\mathrm{H}_{0}$ ditolak, model yang digunakan adalah Fixed Effect.

\section{Uji Hausman}

Merupakan pengujian statistik sebagai dasar pertimbangan yang dilakukan untuk memilih apakah data tersebut menggunakan fixed atau random effect. Hipotesis yang digunakan dalam pengujian ini adalah:

$\mathrm{H}_{0}$ : Model menggunakan Random Effect.

$\mathrm{H}_{1}$ : Model menggunakan Fixed Effect.

Pengujian ini mengikuti distribusi statistik Chi-Squares, dimana kriteria pengambilan keputusan ialah:

- Jika $P$-value $>0.05$ maka $\mathrm{H}_{0}$ diterima, model yang digunakan adalah Random Effect

- Jika $P$-value $<0.05$ maka $\mathrm{H}_{0}$ ditolak, model yang digunakan adalah Fixed Effect.

\section{Uji Langrange Multiplier (LM)}

Merupakan pengujian statistik yang digunakan untuk memilih antara model common effects atau random effects. Uji ini dilakukan jika tahap pertama (uji chow) menghasilkan model common effects lebih bagus daripada model fixed effects.

Jika fixed effect lebih bagus, maka uji LM tidak diperlukan. Hipotesis yang digunakan dalam pengujian ini adalah:

$\mathrm{H}_{0}$ : Model menggunakan Common Effect.

$\mathrm{H}_{1}$ : Model menggunakan Random Effect.

Kriteria pengambilan keputusan dalam uji ini ialah sebagai berikut:

- Jika $P$-value $<0.05$ maka tolak $\mathrm{H}_{0}$, artinya terbukti bahwa random effect model lebih tepat daripada model common effect model.

- Jika $P$-value $>0.05$ maka terima $\mathrm{H}_{0}$; artinya tidak cukup bukti bahwa random effect model lebih tepat daripada common effect model; artinya common effect model lebih bagus.

\section{Pengujian Asumsi Klasik}

Tujuan pengujian asumsi klasik ini adalah untuk memberikan kepastian bahwa persamaan regresi yang didapatkan memiliki ketepatan dalam estimasi, tidak bias dan konsisten. Perlu diketahui, terdapat kemungkinan data aktual tidak memenuhi semua asumsi klasik ini. Beberapa perbaikan, baik pengecekan kembali data outlier maupun recollect error data dapat dilakukan.
Pengujian asumsi klasik diperlukan untuk mengetahui apakah hasil estimasi regresi yang dilakukan benar-benar bebas dari adanya gejala heteroskedastisitas, gejala multikolinearitas, dan gejala autokorelasi. Model regresi akan dapat dijadikan alat estimasi yang tidak bias jika telah memenuhi persyaratan BLUE (Best Linear Unbiased Estimator) yakni tidak terdapat heteroskedastistas, tidak terdapat multikolinearitas, dan tidak terdapat autokorelasi (Sudrajat, 2011).

\section{Pengujian Koefisien Determinasi}

Pengujian ini dilakukan melalui uji koefisien determinasi $\mathrm{R}^{2}$ atau (adjusted $\mathrm{R}^{2}$ ). Koefisien determinasi diinterpretasikan sebagai persentase dari variabel yang dapat dijelaskan oleh persamaan regresi. Koefisien determinasi ini menunjukkan kemampuan garis regresi menerangkan variansi variabel terikat (proporsi variansi variabel terikat yang dapat dijelaskan oleh variabel bebas). Nilai koefisien determinasi $\mathrm{R}^{2}$ atau (adjusted $\mathrm{R}^{2}$ ) berkisar antara 0 sampai 1 . Nilai $\mathrm{R}^{2}$ yang kecil berarti kemampuan variabel-variabel independen dalam menjelaskan variabel dependen amat terbatas. Nilai yang mendekati 1 (satu) berarti variabel-variabel independen memberikan hampir semua informasi yang dibutuhkan untuk memprediksi variasi variabel dependen (Newbold et al. 2010).

\section{Hasil Analisis dan Pembahasan}

\section{Teknik Pemilihan Model Regresi Data Panel}

Uji Chow

\begin{tabular}{ll} 
Tabel 2. Uji Chow & \\
\hline Chow Test & Hasil \\
\hline Nilai F Probabilitas & 0.000882 \\
Keputusan & Fixed Effect Model \\
\hline
\end{tabular}

Sumber : Data diolah Peneliti, 2016

Hasil dari perhitungan F-probabilitas, pada Chowtest sebesar 0.000882 , yang lebih kecil dari 0.05 sehingga dapat dikatakan antara common dan fixed yang menjadi pilihan adalah Fixed Effect Model (FEM).

1. Uji Hausman

Tabel 3. Uji Hausman

\begin{tabular}{ll}
\hline Hausman Test & Hasil \\
\hline F-Probabilitas & 0.5736 \\
Keputuan & Fixed Effect Model \\
\hline
\end{tabular}

Sumber : Data diolah Peneliti, 2016

Hasil dari perhitungan F-probabilitas pada Uji Hausman sebesar 0.5736, yang lebh besar dari 0.05 sehingga dapat dikatakan antara fixed dan random yang di pilihan adalah Fixed Effect Model (FEM). 


\section{Uji LM}

Tabel 4. Uji LM

\begin{tabular}{lll}
\hline F-statistic & 52.14699 & Prob. F(2,134) \\
Obs*R-squared & 61.27372 & Prob. Chi-Square(2)
\end{tabular}

Sumber : Data diolah Peneliti, 2016

Dari uji LM diatas dapat dilihat bahwa nilai chi-square pada tabel diatas menunjukan lebih kecil dari nilai LM hitung maka dapat disimpulkan hasil uji konsisten pada model yang tepat adalah Fixed Effect Model (FEM).

\section{Hasil Uji Asumsi Klasik}

Dengan menggunakan Fixed Effect Model (FEM), untuk menghasilkan nilai parameter model penelitian ini yang lebih tepat, maka model regresi harus dicek apakah terjadi penyimpangan pada asumsi klasik atau tidak.

1. Uji Normalitas

Gambar 2. Hasil Uji Normalitas

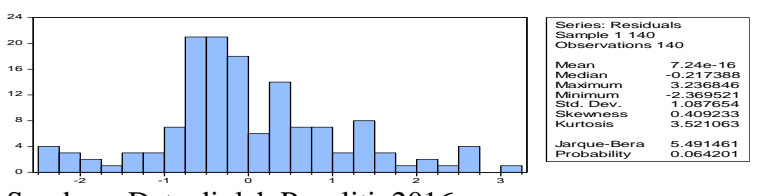

Sumber : Data diolah Peneliti, 2016

Dari histogram diatas nilai probabilitas sebesar 0,064201 yang lebih besar dari 0.05 , sehingga dapat disimpulkan bahwa data dalam penelitian ini berdistribusi normal.

\section{Uji Multikolunieritas}

Tabel 5. Hasil Uji Multikolinearitas

\begin{tabular}{ccc}
\hline Variable & Variance & VIF \\
\hline C & 0.138911 & NA \\
VAHU & 0.014737 & 3.464136 \\
VACA & 0.024048 & 1.001859 \\
STVA & 1.045481 & 3.462746
\end{tabular}

Sumber : Data diolah Peneliti, 2016

Dari uji multikolenearitas diatas terlihat nilai VIF yang lebih kecil dari 10, sehingga dapat dikatakan bahwa model regresi ini terbebas dari masalah multikolinearitas.

\section{Uji Autokorelasi}

Tabel 6. Hasil Uji Autokorelasi

\begin{tabular}{lr}
\hline Uji Autokorelasi & \multicolumn{1}{l}{ Hasil } \\
\hline Prob(F-statistic) & 0.000000
\end{tabular}

Sumber : Data diolah Peneliti, 2016

Dari tabel diatas F probabilitas sebesar 0,000 yang lebih kecil dari 0.05 , sehingga dapat disimpulkan bahwa data dalam penelitian ini ada masalah autokorelasi, tetapi pada data panel dan time series tidak diperlukan uji autokorelasi. Dan dari tabel uji DW tersebut antara dU dan $(4-d U)=1.656<1.94<2.90$, maka dapat disimpulkan bahwa tidak ada autokorelasi atau tidak terdapat autokorelasi positif maupun negatif pada data yang diuji.

\section{Uji Heteroskedastisitas}

Tabel 7. Hasil Uji Heteroskedastisitas

\begin{tabular}{ll}
\hline Prob(F-statistic) & 0.059945
\end{tabular}

Heteroskedasticity Test: Breusch-Pagan-Godfrey

\begin{tabular}{ll}
\hline F-statistic & 2.528672 \\
Obs*R-squared & 7.396559 \\
Scaled explained SS & 8.798429
\end{tabular}

Sumber : Data diolah Peneliti, 2016

Dari tabel diatas F probabilitas (F-statistic) sebesar 0.0599 yang lebih besar dari 0.05, Sehingga dapat disimpulkan bahwa data dalam penelitian ini terbebas masalah heteroskedastisitas.

Dengan Heteroskedasticity Test: Breusch-Pagan-Godfrey diketahui bahwa tidak ada masalah heteroskedastisitas karena probability dari obs*R squared lebih besar dengan tingkat $\alpha=$ $5 \%$ tetap didapatkan kesimpulan yang sama, yaitu penerimaan $\mathrm{H}_{0}$, yang berarti memang tidak ada heteroskedasti-sitas.

\section{Uji t (Uji Partial)}

Pengujian model regresi secara parsial digunakan untuk mengetahui apakah masing-masing variabel bebas pembentuk model regresi secara individu mempengaruhi variabel terikat atau tidak.

Tabel 8. Hasil Uji T (Uji Partial)

\begin{tabular}{lrrrr}
\hline Variable & Coefficient & Std. Error & t-Statistic & \multicolumn{1}{l}{ Prob. } \\
\hline VAHU & 0.015996 & 0.120577 & 0.132662 & 0.8947 \\
VACA & 0.093121 & 0.142566 & 0.653175 & 0.5150 \\
STVA & 2.080231 & 1.015237 & 2.049010 & 0.0428 \\
C & 0.780024 & 0.385297 & 2.024476 & 0.0453 \\
\hline
\end{tabular}

Sumber : Data diolah Peneliti, 2016

Berdasarkan hasil penelitian menggunakan model Fixed Effect besarnya nilai probabilitas untuk variabel VAHU ialah sebesar 0.8947 dimana nilai ini $>0.05$. Berdasarkan tingkat kepercayaan $95 \%$, dapat ditarik kesimpulan bahwa $\mathrm{H}_{0}$ diteriima. Dengan demikian VAHU berpengaruh tidak signifikan terhadap kinerja perusahaan (ROA) dengan koefisien beta sebesar 0.015996 yang berarti setiap ada peningkatan variabel VAHU sebesar satu satuan maka akan meningkatkan ROA sebesar 0.015996, untuk variabel VACA ialah sebesar 0.5150 dimana nilai ini > 0.05 . Berdasarkan tingkat kepercayaan $95 \%$, dapat ditarik kesimpulan bahwa $\mathrm{H}_{0}$ diteriima.

Dengan demikian VACA berpengaruh tidak signifikan terhadap kinerja perusahaan (ROA) dengan koefisien beta sebesar 0.093121yang berarti setiap ada peningkatan variabel VACA sebesar satu satuan maka akan meningkatkan ROA sebesar 0.093121 danuntuk variabel STVA ialah sebesar 0.0428 dimana nilai ini $<0.05$. Berdasarkan tingkat kepercayaan 95\%, dapat ditarik kesimpulan bahwa $\mathrm{H}_{0}$ ditolak. Dengan demikian STVA berpengaruh signifikan terhadap kinerja perusahaan (ROA) 
dengan koefisien beta sebesar 2.080231yang berarti setiap ada peningkatan variabel STVA sebesar satu satuan maka akan meningkatkan ROA sebesar 2.080231.

Hal ini sesuai dengan yang dijelaskan pada intellectual capital bahwa penambahan gaji, tunjangan, bonus karyawanya oleh perusahaan akan diartikan oleh investor bahwa perusahaan cukup yakin akan peningkatan kemampuan perusahaan untuk menghasilkan keuntungan di masa yang akan datang sehingga perusahaan berani menaikkan porsi gaji, tunjangan, bonus karyawanya. Oleh karena itu kenaikan porsi tunjangan, bonus karyawanya direspon positif oleh investor.

\section{Uji Statistik F (Uji Dampak Simultan)}

Berdasarkan perhitungan F-test pada hasil estimasi model fixed effect diperoleh hasil F-hitung sebesar 4.295777 dengan nilai signifikansi (sig) sebesar 0.000000. Dikarenakan nilai signifikansi $<0.05$, dengan tingkat kepercayaan 95\% maka $\mathrm{H}_{0}$ ditolak. Dapat disimpulkan bahwa terdapat dampak simultan yang signifikan antara yang dapat dikatakan bahwa VAIC TM (VAHU, VACA, STVA) secara bersama-sama memiliki pengaruh terhadap kinerja perusahaan (ROA). Hasil penelitian ini sesuai dengan yang diungkapkan oleh Salehi et al., (2014).

\section{Pengujian Koefisien Determinasi}

Tabel 9. Fixed Effect Model (Uji Simultan)

R-squared 0.497085

Adjusted R-squared

0.381370

Sumber : Data diolah Peneliti, 2016

Nilai adjusted $\mathrm{R}^{2}$ yaitu 0.381370 yang berarti bahwa variasi variabel ROA dapat dijelaskan oleh variabel VAHU, VACA dan STVA adalah sebesar 0.381370 atau sebesar $38.14 \%$ sedangkan sisanya sebesar $61.86 \%$ dijelaskan oleh faktorfaktor lain yang tidak terdapat dalam penelitian ini.

Tabel 10. Pengaruh Variabel Independen dan Variabel Dependen

\begin{tabular}{lll}
\hline Variabel & $\begin{array}{c}\text { Pengaruh yang } \\
\text { ditemukan }\end{array}$ & Signifikansi \\
\hline VAHU & Positif & $\begin{array}{l}\text { Tidak } \\
\text { signifikan }\end{array}$ \\
VACA & Positif & $\begin{array}{l}\text { Tidak } \\
\text { signifikan }\end{array}$ \\
STVA & Positif & Signifikan \\
VAIC & Positif & Signifikan \\
\hline Sumber $:$ Data diolah Peneliti, 2016 &
\end{tabular}

Sumber : Data diolah Peneliti, 2016

\section{Model Regresi Data Panel}

Berdasarkan hasil Fixed Effect Model tersebut juga diperoleh persamaan regresi antara intellectual capital yang diproksikan oleh VAHU, VACA, STVA ;terhadap kinerja perusahaan (financial performance) yang diproksi oleh ROA.

$$
\begin{aligned}
\mathrm{Y}_{\mathrm{it}}= & \alpha+\beta_{1} \mathrm{X}_{\mathrm{it}}+\beta_{2} \mathrm{X}_{\mathrm{it}}+\beta_{3} \mathrm{X}_{\mathrm{it}}+\varepsilon_{\mathrm{it}} \\
\mathrm{ROA}= & 0.780024+0.015996 \text { VAHU }+0.093121 \\
& \text { VACA }+2.080231 \text { STVA }
\end{aligned}
$$

\section{Kesimpulan}

Berdasarkan hasil penelitian ini dapat diperoleh kesimpulan pada perusahaan sektor perbankan yang terdaftar di Bursa Efek Indonesia selama periode 2010-2014 :

1. VAHU berpengaruh tidak signifikan dan hubungan positif terhadap kinerja perusahaan (ROA).

2. VACA berpengaruh tidak signifikan dan hubungan positif terhadap kinerja perusahaan (ROA).

3. STVA berpengaruh signifikan dan hubungan positif terhadap kinerja perusahaan (ROA).

4. VAHU, VACA dan STVA terdapat dampak simultan yang signifikan terhadap kinerja perusahaan (ROA).

Berdasarkan hasil analisis data dapat diketahui bahwa variabel yang paling berpengaruh pada penelitian ini ialah STVA dengan nilai koefisien sebesar 2.080231. STVA berpengaruh signifikan dan hubungan positif terhadap kinerja perusahaan yang di-proxy-kan dengan ROA. Berdasarkan hasil pengujian dengan model Fixed Effect, besarnya nilai Adjusted R-squared yaitu 0.381370 yang berarti bahwa variasi variabel ROA dapat dijelaskan oleh variabel VAHU, VACA dan STVA adalah sebesar 0.381370atau sebesar $38.1370 \%$ sedangkan sisanya sebesar $61.827 \%$ dijelaskan oleh faktor-faktor lain yang tidak terdapat dalam penelitian ini.

\section{Implikasi Manajerial}

Implikasi manajerial dari penelitian ini adalah sebagai berikut:

\section{Perusahaan}

Manajemen perusahaan perlu mempertimbang-kan pengembangan sumber daya intangible (intangible asset), karena intangible asset yang sulit ditiru ini mampu membawa perusahaan semakin maju, semakin kompetitif, inovatif dan mampu menjadi pemenang dalam lingkup persaingan global yang semakin ketat. Perusahaan selalu mengarahkan dan terus menginvestasikan baik melalui $\mathrm{R} \& \mathrm{D}$, pelatihan sertifikasi demi meraih keunggulan bersaing pada perusahaan terkait. Perusahaan perbankan di Indonesia lebih mengandalkan STVA atau pengalaman struktural tenaga kerja dibandingkan bagaimana melatih, membina dan mengembangkan potensi sumber daya manusia dari awal. Secara umum hubungan intellectual capital dengan financial performance signifikan dan hubungannya positif.

\section{Investor}

Pihak investor akan memilih perusahaan tentunya dengan kinerja yang unggul didukung oleh sumber daya non fisik : intangible assets, intellectual capital dapat dijadikan sebagai faktor yang menentukan financial return suatu perusahaan karena dipandang sebagai suatu aktivitas dasar untuk pencapaian, pertumbuhan, dan pendukung sumber-sumber 
penting perusahaan. Intellectual capital suatu perusahaan diinterpretasikan sebagai indikator awal bagi perkembangan kinerja dari suatu perusahaan pada masa mendatang dan nilai perusahaan dimasa yang akan datang memberikan keuntungan jangka panjang dan kontinyu.

\section{Saran untuk Penelitian Selanjutnya}

Saran yang dapat diberikan untuk pihak yang terkait serta peneliti selanjutnya adalah sebagai berikut:

1. Obyek penelitian yang digunakan agar dapat diperluas untuk mendapatkan gambaran secara menyeluruh tentang kondisi persaingan, keunggulan dan inovasi-inovasinya, kaitkan lokasi negara lain di dunia untuk mengetahui pengaruh dan hubungannya secara global.

2. Penggunaan variabel-variabel lain baik internal perusahaan seperti ROE, EPS, PER, PBV, NIM, ROI/ROCE, dan lain sebagainya.

\section{Daftar Puataka}

Abdullah, D. F \& S. Sofian. 2012. "The Relationship Between Intellectual Capital and Corporate Performance". Procedia-Social Behavioral Science, 40(3), 537-541

Anderson, D. R., Sweeney, D. J., \& Williams., T. A. 2011. Statistic for Business and Economics 1 le. South Western : Cengage Learning.

Besharati, E,; S Kamali,; E Heydari Mazhari \& S. Mahdavi 2012. "An Investigation of The Relationship of Intellectual Capitaland Innovation Capital with Financial Performance and Value of Companies Listed in Tehran Stock Exchange," Journal of Basic and Applied Journal of Management Reviews,

Bontis, N. 1998. Intellectual Capital: An Exploratory Study that Develops Measures and Model. Management Decision, 36(2), 63-76.

Bontis, N., Keow W.C.C and Richardson, S., 2000. Intellectual Capital and Business Performance in Malysian Industries,Journal of Intellectual Capital, I:85-100

Bontis, N. 2001. Assessing Knowledge Assets: A Review of the Models Used to Measure Intellectual Capital. International Journal ofManagement Reviews, 3(1), 41-60.

Bontis, N., 2001. Managing Organizational Knowledge by Diagnostic Intellectual Capital : Framing and Advancing the State of the Field, in World Congress Intellectual Capital Readings, Butterworthheinemmann, Boston, MA : 13-56

Bontis, N. 2004. National Intellectual Capital Index: A United Nations Initiatives for the Arab Region.Journal of Intellectual Capital, 5(1), 13-39.

Firrers, S., and Williams, S.M., 2003. Intellectual Capital and Traditional Measures of Corporate Performance.Journal of Intellectual Capital, 4(3), $348-360$
Gujarati, Damodar. 2005. Ekonometrika Dasar, terjemahan, Sumarno Zain, Penerbit Erlangga, Jakarta

Kujansivu, Paula dan Lönnqvist, Antti. 2007. Investigating the Value and Efficiency of Intellectual Capital, Journal of Intellectual Capital.8:2, 272-287.

Jogiyanto, H. 2004, Metodologi Penelitian Bisnis, edisi 20042005, BPFE, Jogyakarta.

Nachrowi, DN. Dan Usman, Hardius. 2010. Pendekatan Populer dan Praktis Ekonometrika Untuk Analisis Ekonomi dan Keuangan. Cetakan Kedua. Jakarta: Lembaga Penerbit Fakultas Ekonomi.

Newbold, Paul et al., 2010. Statistic for Business and Economics. New Jersey : Pearson Education, Inc.

Nogueira, C. G; J F. Aguir \& L. C Basso. 2010 "Intellectual Capital and Probability in the Learher Set Up, Leather Artificats, Traveling Products and Footwear Sector in Brazil". Journal of International Finance and Economics, 10.11(1), 79-90

Pulic, A. 2000. "Measuring the Performance of Intellectual Potential in Knowledge Economy". Paper presented at the 2nd McMaster Word Congress on Measuring and Managing Intellectual Capital by the Austrian Team for Intellectual Potential.

Pulic, A. 2004, Basic Information on VAIC. http://www.vaiceon.net

Riahi-Belkaoui, A. 2003. Intellectual Capital and firm Performance of US Multinational Firms: a Study of the Resource-Based and Stakeholder Views. Journal of Intellectual Capital. Vol. 4 No. 2. pp. 215-226.

Richieri, F. L,;L. C Basso \& D. D. Leiva Martin. 2008. Intellectual Capital and the Creation of Value in Brazilian Companies.

Rudez, H. N. \& Mihalic, 2007. Intellectual Capital in the Hotel Industry: A Case Study from Slovenia", International Journal Hospitality Management, 26(1), 188-189

Salehi, Mohdi, et al., 2014. The Relationship Between Intellectual Capital with Economic Value Added and Financial Performance. Iranian Journal of Management Studies, Vol. 7, No. 2 pp:259-283. Ferdowsi University of Mashdad and Islamic Azad University Iran.

Shochrul Ajija, R. 2011. Cara Cerdas Menguasai EViews.Salemba Empat. Jakarta

Sudrajat, S.W.M, 2011. Mengenal Ekonometrika Pemula, Penerbit CV. Armco, Edisi ketiga. Cetakan kedua. Bandung

Sugiono. 2011. Metode Penelitian Bisnis. CV. Alfabeta, Buku kedua. Cetakan ketiga. Bandung

Tan, H.P., Plowman, D., and Hancock, P, 2007.Intellectual Capital and Financial return of Companies.Journal of Intellectual Capital. 8 (1) : 76-95 
Jurnal Ekonomi dan Bisnis Indonesia

Ting, I.W.K., and Lean, H.H. 2009. Intellectual Capital Performance of Financial Institutions in Malaysia. Journal of Intellectual Capital. 10 (4): 588-599

Widarjono, Agus 2007. Ekonometrika: Teori dan Aplikasi Untuk Ekonomi dan Bisnis, edisi kedua. Yogyakarta: Ekonisia FE Universitas Islam Indonesia.
Zeghal, D. \& A. Maaloul. 2010. Analyzing Value Added as an Indicator of Intellectual Capital and its Consequences on Company Performance, Journal of Intellectual Capital, 11(1), 39-60. 